\section{Datasimulering nyttig ved studier av hiv?}

\author{
Datasimulering gir nye muligheter \\ til å forutsi effekten av kombina- \\ sjonsbehandling mot hiv-1-infek- \\ sjon.
}

Det er utviklet nesten 30 antivirale legemidler for behandling mot hivinfeksjon, og disse brukes som regel i kombinasjoner med minst tre ulike virkestoffer. Legemidlene er satt sammen basert på resultater fra kliniske forsøk, men det er kostbart og upraktisk å teste alle mulige legemiddelkombinasjoner. Amerikanske forskere har nå utviklet en kvantitativ modell med datasimulering, såkalt in silico, til å kvantitere effekten av de enkelte medikamenter i kombinasjon (1).

Tre ulike antivirale legemidler ble brukt. Forskerne kunne påvise hittil ukjent og komplisert farmakodynamikk som bestemmer det hemmende potensialet ved kliniske konsentrasjoner av legemidlene. Modellen gjør det mulig å sammenlikne effekt av ulike antivirale kombinasjonsbehandlinger, forene resultater fra kliniske forsøk og danne grunnlaget for å optimalisere behandlingen av hivinfeksjon.

- Dette er en spennende tilnærming, sier førsteamanuensis og overlege Anne-Marte Bakken Kran ved Mikrobiologisk avdeling, Oslo universitetssykehus, Ullevål. Resultatene fra datasimuleringen samsvarer relativt godt med eksperimentelle data, Datasimulering vil ikke kunne erstatte kliniske studier, men kan være et nyttig supplement som grunnlag for generelle anbefalinger, særlig for optimalisering av dose. Modellen kan også tenkes brukt til å selektere hvilke medikamentkombinasjoner som er mest aktuelle for klinisk utprøving,

- Ved valg av behandlingsregime for den enkelte pasient er det imidlertid mange andre faktorer enn den antivirale effekten å ta hensyn til, slik som resistens, bivirkninger, etterlevelse, individuell toleranse og interaksjoner. Det er vanskelig å se for seg at datasimulering kan erstatte den gode kliniske vurdering, sier Kran.

\section{Trine B. Haugen}

trine.b.haugen@hioa.no

Tidsskriftet

\section{Litteratur}

1. Jilek BL, Zarr M, Sampah ME et al. A quantitative basis for antiretroviral therapy for HIV-1 infection. Nat Med 2012; 18: 446-51.

\title{
Kartlegging av tobakksbruk
}

\section{I mange lavinntekts- og mellominntektsland er det en høy andel som bruker tobakk, særlig blant menn. I den yngre generasjonen starter også kvinner i ung alder.}

I rike land kan $18 \%$ av dødsfallene tilskrives tobakksbruk, mens tilsvarende tall i de fattigste landene er $4 \%$. Med endrede tobakksvaner antas disse tallene å forandre seg (1). Resultater fra den første global adult tobacco survey (GATS) omfatter de 14 lavinntekts- og mellominntektslandene som har flest voksne røykere: Bangladesh, Brasil, Egypt, Filippinene, India, Kina, Mexico, Polen, Russland, Thailand, Tyrkia, Ukraina, Uruguay og Vietnam $(1,2)$. Samlet sett brukte $48,6 \%$ av mennene og $11,3 \%$ av kvinnene i disse landene tobakk, hovedsakelig i form av sigaretter. Blant eldre tobakksbrukere (55-64 år) hadde kvinnene startet i høyere alder enn mennene, mens det ikke var en slik forskjell hos yngre (25-34 år). Det var få $(<20 \%)$ som hadde sluttet å bruke tobakk i Kina, India, Egypt, Russland og Bangladesh (1).

Sosioøkonomiske variabler assosiert med tobakksbruk ble analysert i 13 av de 14 GATSlandene (Brasil holdt utenfor pga. usammen- liknbare datal (2). Ved spørreundersøkelse blant totalt 209027 personer fant man at det generelt er høyere grad av tobakksbruk blant folk i urbane strøk med lavere utdanning og mindre kjennskap til helseskadelige effekter av tobakk, men disse forskjellene er ikke store og gjenfinnes ikke i alle landene. Flere menn enn kvinner brukte tobakk i alle landene, med størst forskjell mellom kjønnene i Egypt og minst i Polen.

\section{Kristoffer Brodwall \\ kristoffer.brodwall@gmail.com \\ Barneklinikken}

Haukeland universitetssykehus

\section{Litteratur}

1. Giovino GA, Mirza SA, Samet JM et al. Tobacco use in 3 billion individuals from 16 countries: an analysis of nationally representative cross-sectional household surveys. Lancet 2012; 380: 668-79.

2. Palipudi KM, Gupta PC, Sinha DN et al. Social determinants of health and tobacco use in thirteen low and middle income countries: evidence from Global Adult Tobacco Survey. PLoS ONE 2012; 7: e33466.

\section{Underernæring kan gi kolitt}

\author{
Museforsøk viser hvordan under- \\ ernæring kan disponere for \\ inflammasjon i tarmslimhinner \\ og for diarésykdom.
}

Et menneske har mer enn ti ganger flere mikrober i tarmen enn egne celler, og det er et tett samspill mellom tarmmikrober, tarmepitelet og slimhinnens immunapparat. Museforsøk som belyser dette samspillet har vist hvordan underernæring kan disponere for sykdom.

Mus som ikke absorberer tryptofan gjennom tynntarmen, enten fordi de fikk tryptofanfattig kost eller hadde et defekt transportprotein, fikk kraftig kolitt som reaksjon på et lett kjemisk irritament (1). De produserte også mindre mengder antimikrobielle peptider som utskilles i tynntarmen og som virker nedstrøms. Disse peptidene påvirker mikrobefloraen i tykktarmen - når mikrober fra kolittmus fikk kolonisere mikrobefrie mus, ble også disse mottakelige for kolitt.

Hvordan tryptofanmangelen virker, vet man ennå ikke. Muligens kan en metabolitt enten via proteinkinasen mTOR eller mer indirekte via lymfocytter som produserer interleukinene 17 og 22, stimulere peptidsekresjonen som kan endre tarmens mikrobiom.

- Disse musene fikk ikke kolitt spontant, sier overlege Arnold Berstad ved Unger-Vetlesens institutt, Lovisenberg Diakonale Sykehus. Kolitten forårsaket av et irritament var uvanlig kraftig, og kunne motvirkes ved å gi tryptofan eller tryptofanmetabolitten niacid, altså vitamin $\mathrm{B}_{3}$. Niacidmangel er årsak til pellagra, som har diaré som ett sykdomstegn, men om den eksperimentelle kolitten er relevant for mennesker, er usikkert.

Mangel på tryptofan kan forårsake problemer på flere måter. Tryptofan er blant annet substrat for serotoninsyntesen i de enteroendokrine cellene i tarmen. Man kan spekulere på om visse kroniske infeksjoner kan gi serotoninmangel, fordi det infeksiøse agens spiser opp tryptofan. Serotonin har viktige motoriske effekter i tarmen og psykologiske effekter i sentralnervesystemet, men i denne studien ble serotonin ikke undersøkt, sier Berstad.

\section{Haakon B. Benestad}

h.b.benestad@medisin.uio.no

Universitetet i Oslo

\section{Litteratur}

1. Hashimoto T, Perlot T, Rehman A et al. ACE2 links amino acid malnutrition to microbial ecology and intestinal inflammation. Nature 2012; 487: 477-81. 